\title{
Pengembangan Potensi Wisata Situ Rawagede Desa Sirnajaya Melalui Pemetaan Partisipatif (Studi Kasus: Desa Sirnajaya Kecamatan Suka Makmur Kabupaten Bogor)
}

\section{${ }^{1}$ Mohamad Mahfudz, ${ }^{2}$ Rudi Admawidjadja}

Prodi Teknik Geodesi, Fakultas Teknik Universitas Pakuan, Jl. Pakuan Po Box 452 Bogor 16143, Jabar, Indonesia

\section{Email Korespodensi : m.mahfudz59@gmail.com}

\begin{tabular}{|c|c|}
\hline Artic & \\
\hline $\begin{array}{l}\text { Artic } \\
\text { Rece } \\
\text { Revis } \\
\text { Publi }\end{array}$ & \multirow{2}{*}{$\begin{array}{l}\text { Development of Tourism Potential in Situ Rawa Gede, Sirnajaya Village } \\
\text { through Participatory Mapping (Case Study: Sirnajaya Village, Suka } \\
\text { Makmur District, Bogor Regency). This Community Service Activity aims to } \\
\text { assist Sirnajaya Village in participatory mapping of Situ Rawa Gede potential as } \\
\text { a reference in spatial planning. The method used for spatial planning was } \\
\text { participatory mapping. The team attempted to map the natural potential of Situ } \\
\text { Rawa Gede so that the development of tourism potential was integrated between } \\
\text { supply and demand. Participatory mapping is a mapping process that involves } \\
\text { the community in data and data analysis of the problems they face with current } \\
\text { mapping technology. The result of this activity was the formation of a map of the } \\
\text { Situ Rawa tourism distribution as a basis for tourism development based on its } \\
\text { potential. In the restaurant, the community is fully involved because they are the } \\
\text { ones who see the history, land use, the potential of the village, and their hopes for } \\
\text { the future. }\end{array}$} \\
\hline $\begin{array}{l}\text { Keywords } \\
\text { Tourism, } \\
\text { Situ Rawa Gede, } \\
\text { Participatory Mapping }\end{array}$ & \\
\hline Info & \\
\hline Dipublikasi:30-10-2020 & \multirow{2}{*}{$\begin{array}{l}\text { Kegiatan Pengabdian Kepada Masyarakat ini bertujuan untuk membantu Desa } \\
\text { Sirnajaya dalam melakukan pemetaan potensi Situ Rawa Gede secara partisipatif } \\
\text { sebagai acuan dalam tata ruang. Metode yang digunakan untuk penataan ruang } \\
\text { tersebut adalah dengan melakukan pemetaan partisipatif, tim berupaya } \\
\text { memetakan potensi alam Situ Rawa Gede agar pengembangan potensi pariwisata } \\
\text { terpadu antara suply and demand. Pemetaan partisipatif merupakan proses } \\
\text { pemetaan yang melibatkan masyarakat dalam pengumpulan data dan analisis data } \\
\text { terkait permasalahan yang mereka hadapi dipadukan dengan teknologi pemetaan } \\
\text { saat ini. Hasil dari kegitan ini terbentuknya peta sebaran fasilitas wisata Situ } \\
\text { Rawa sebagai daras pengembangan wisata berdasarkan potensi yang dimiliki. } \\
\text { dalam pembentukannya masyarakat terlibat secara penuh karena merekalah yang } \\
\text { mengetahui sejarah, penggunaan lahan, potensi desa, dan harapannya di masa } \\
\text { depan. }\end{array}$} \\
\hline & \\
\hline
\end{tabular}

Sitasi: Mahfudz M. \& Admawidjadja R. (2020) Pengembangan Potensi Wisata Situ Rawagede Desa Sirnajaya Melalui Pemetaan Partisipatif (Studi Kasus : Desa Sirnajaya Kecamatan Suka Makmur Kabupaten Bogor. Sasambo: Jurnal Abdimas (Journal of Community Service). 2(3)163-171 DOI : 10.36312/sasambo.v2i3.275

\section{PENDAHULUAN}

Di era pandemi covid 19 tahun 2020 perekonomian yang paling terdampak adalah sektor pariwisata, oleh karena itu pemerintah sedang berupaya dengan serius mengatasi keterpurukan di sektor pariwisata tersebut. Pariwisata merupakan salah satu fenomena sosial, ekonomi, politik, budaya, dan teknologi, sehingga keadaan ini menjadi sebuah perhatian yang besar dari pemerintah untuk perencanaan pembangunan.Pariwisata adalah segala sesuatu 
yang berhubungan dengan wisata termasuk juga pengusahaan obyek serta daya tarik wisata serta usaha-usaha yang terkait dengan bidang tersebut (Choridotul, Wahyu \& Sudarti, 2018).

Berkembangnya pariwisata di suatu daerah akan mendatangkan banyak manfaat bagi masyarakat, yakni secara ekonomis, sosial dan budaya. Namun, jika pengembangannya tidak di persiapkan dan dikelola dengan baik, justru akan menimbulkan berbagai permasalahan yang menyulitkan atau bahkan merugikan masyarakat (Damayanti, 2014). Situ Rawa Gede merupakan wisata alam di Desa Sirnajaya Kecamatan Sukamakmur Kabupaten Bogor yang belum banyak dijamah wisatawan. Padahal keindahannya berada di tengah perbukitan, sawah, dan curug yang asri, sehingga memiliki daya tarik bagi para wisatawan baik dari Bogor maupun daerah lainnya. Pemerintah Daerah memiliki peran penting untuk mengembangkan potensi pariwisata tersebut supaya bisa meningkatkan daya saing dan peningkatan taraf hidup bagi masyarakat sekitarnya (Travel. Kompas. Com, 2018).

Desa merupakan wilayah terkecil dalam pemerintahan di Republik Indonesia, untuk pemerataan pembangunan yang berkeadilan maka perlu adanya penggalian potensi dan penataan ruang yang dimiliki oleh pemerintah tingkat Desa. Penggalian potensi tersebut akan semakin mudah apabila didukung dengan peta dan informasi geospasial yang memadai, berdasarkan UU IG No. 042011 menjamin ketersediaan dan akses informasi geospasial yang bisa dipertanggungjawabkan untuk mewujudkan kegunaan dan keberhasilan informasi IG melalui kerjasama. Pengelolaan sumber daya yang dimiliki desa memerlukan peta dan informasi geospasial untuk menunjukkan potensi dari desa tersebut. Pemetaan partisipastif merupakan metode alternatif dalam penyediaan informasi geospasial. Dengan adanya undang-undang yang mengatur maka masyarakat dapat dilibatkan dalam pemetaan desa mereka sendiri.

Pemetaan Partisipatif pada prinsipnya sama dengan pemetaan pada umumnya yang sering dilakukan oleh instansi pemerintah. Perbedaannya adalah pelaksana dari pemetaan tersebut, pada pemetaan partisipatif dalam pengukurannya diikuti oleh banyak anggota suatu komunitas masyarakat, yang pada praktek pemetaan biasa dapat dilaksanakan 2 orang saja. Perbedaan yang lain adalah tentang tema, masyarakat akan menentukan sendiri tentang tema yang dianggap penting (ESP, 2007). Dalam proses pemetaan Potensi Wisata Situ Rawagede Desa Sirnajaya tim pengabdian melibatkan stakeholder setempat.

Pelibatan masyarakat dan stakeholder dalam pemetaan potensi desa sangat diperlukan karena merekalah yang mengetahui sejarah, tataguna lahan, potensi desa, dan harapan mereka dimasa depan. Dengan pemetaan partisipatif ini diharapkan menyadarkan masyarakat tentang arti pentingnya sebuah batas wilayah desa, hak-hak atas tanah dan sumber daya alam mereka. dengan peta bisa menghindarkan konflik antar desa karena mereka mengetahui wilayahnya dan siapa yang berhak mengelola wilayah tersebut. Semangat pemetaan partisipatif mampu mengindentifikasi potensi kearifan lokal, pranata hukum desa, dan kelembagaan yang ada diwilayahnya (Hapsari \& Cahyono, 2015).

Kegiatan pengabdian masyarakat ini bertujuan untuk membantu Desa Sirnajaya dalam pembuatan peta secara partisipatif agar bisa menjadi acuan dalam tata ruang desa untuk pengembangan potensi parisiwisata Situ Rawa Gede.

\section{METODE PELAKSANAAN}

Pengabdian kepada masyarakat ini dilaksanakan di Desa Sirnajaya Kecamatan Suka Makmur Kabupaten Bogor Jawa Barat. Data yang digunakan dalam penelitian ini adalah Peta RBI Skala 25000 dan peralatan yang digunakan dalam pelaksanaan pengabdian ini berupa perangkat keras yaitu 1) GPS handheld, 2) Kamera, dan 3) Komputer Pengolah Data.

\section{Pengolahan Data}

Berikut merupakan diagram alir proses pengolahan data pada PKM

1. Peta RBI Skala 25000NLP 1209-142 
Data yang digunakan pada PKM ini adalah peta RBI skala 25000, peta tersebut digunakan untuk mengetahui posisi dan lokasi di permukaan bumi.

2. Pengukuran

Pelaksaanaanpengukuran bersama aparat Desa dan masyarakat sekitar,tujuandari pengukuran untuk mendapatkan koordinat $\mathrm{X}, \mathrm{Y}$ dan $\mathrm{Z}$, koordinat tersebut digunakan untuk mengetahui posisi dan ketinggian suatu tempat.

3. Ploting

Proses ploting data koordinat hasil pengukuran pada komputer untuk proses penggambaran peta

4. Hasil dan Penyajian data

Hasil akhir dari PKM ini adalah peta potensi Situ Rawa Gede dan Fasilitasnya

\section{HASIL DAN PEMBAHASAN}

Suvey Fasilitas Situ Rawa Gede

Pada pelaksanaan survey menggunakan GPS Handheald metode pengambilan data pada umumnya mencakup 4 hal utama yaitu : pertama seting GPS dalam kondisi waypoint, kedua pastikan bahwa sinyal di GPS sudah utuh, ketiga lokasi tidak tertutup dengan benda lain dan yang keempat lokasi pengambilan data harus mendekati obyek yang diambil koordinatnya. Pengambilan data dari GPS pada dasarnya adalah bertujuan untuk mendapatkan data koordinat relatif (dX, dY, dZ).

Dalam Survey fasilitas Situ Rawa Gede melibatkan aparat Desa dan masyarakat sekitar karena mereka yang mengetahui posisi-posisi fasilitas dan rencana pengembangannya.Pelaksanaan survey bertujuanuntuk mendapatkan posisi dan letak-letak fasilitas Situ Rawa Gede. Data yang diperoleh dari survey tersebut berupa koordinat dan ketinggian,adapun koordinat tersebut seperti tertera pada tabel dibawah ini :

Tabel 1. Koordinat dan elevesi Fasilitas Situ Rawa Gede

\begin{tabular}{|c|c|c|c|}
\hline \multicolumn{2}{|c|}{ Koordinat } & Elevasi & \multirow{2}{*}{ Nama Tempat } \\
\hline $\mathbf{X}$ & $\mathbf{Y}$ & $\mathbf{Z}$ & \\
\hline 720328 & 9267049 & $972 \mathrm{~m}$ & Area Tiketing \\
\hline 720304 & 9267014 & 977 m & Area Parkir \\
\hline 720304 & 9267014 & $977 \mathrm{~m}$ & Kedai Kopi Rawa Gede \\
\hline 720158 & 9266888 & $982 \mathrm{~m}$ & Jembatan Tengah Danau \\
\hline 720171 & 9266870 & $989 \mathrm{~m}$ & Kolam Renang dan Kolam Ikan \\
\hline 720220 & 9266720 & $989 \mathrm{~m}$ & Camping Ground \\
\hline 720248 & 9266813 & $988 \mathrm{~m}$ & Sarana Ibadah \\
\hline 720083 & 9266517 & $1167 \mathrm{~m}$ & Kebun Kopi \\
\hline 719999 & 9266402 & $1188 \mathrm{~m}$ & Tempat Istirahat Menuju Curug Cidulang \\
\hline 719989 & 9266257 & $1188 \mathrm{M}$ & Curug Cidulang \\
\hline
\end{tabular}

\section{Fasilitas Wisata Situ Rawa Gede}

Adapun beberapa fasilitas yang sudah dibangun oleh pengelola Situ Rawa Gede adalah sebagai berikut :

1. Area Tiketing

Para wisatawan yang berkunjung ke obyek wisata Situ Rawa Gede di kenai biaya 20 ribu per orang parkir motor 5000 dan parkir mobil 10.000. sebelum masuk area wisata pengunjung melakukan pendaftaran di loket yang telah disediakan pengelola. Area tiketing di jaga oleh 2 orang 1 (satu orang) bertugas sebagai petugas pembayaran dan 1 (satu) orang lagi sebagai pengatur kendaraan.

$\begin{array}{ll}\text { Koordinat } & : 720328 ; 9267049 \\ \text { Elevasi } & : 972 \mathrm{~m}\end{array}$ 


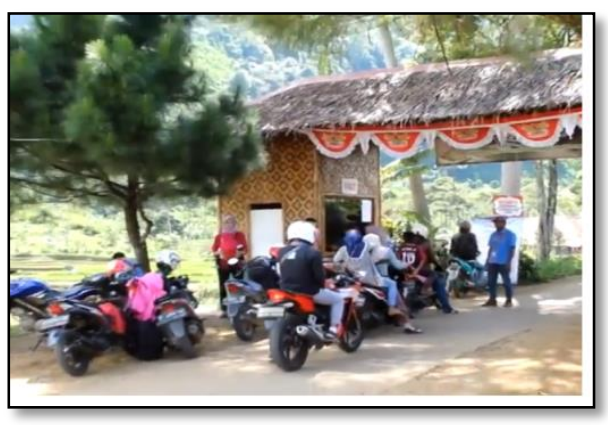

Gambar 1. Area Tiketing

\section{Area Parkir}

Pengelola Situ Rawa Gede menyediakan lahan pakir yang cukup luas kurang lebih $1 \mathrm{Ha}$ sehingga bisa menampung banyak kendaraan baik kendaraan roda 4 maupun roda, di area parkir tersebut terpampang baliho besar yang menunjukkan nama obyek wisata Rawa Gede Agrowisata Kopi.

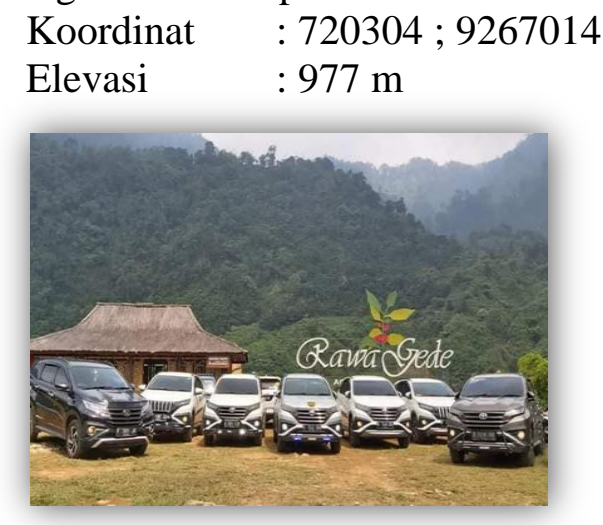

\section{Gambar 2. Area Parkir}

\section{Kedai Kopi Rawa Gede}

Sambilistirahat menghilangkan lelah kita bisa ngopi di Kedai Kopi Rawa Gede dan menikmati panorama yang indah di Kaki Bukit Kencana yang mengitari Situ Rawa Gede.Kopi Rawa Gede merupakan hasil perkebunan warga di sekitar Situ Rawa Gede yang di kelola oleh BUMDES Sinar Makmur.

Koordinat : $720304 ; 9267014$

Elevasi : $: 977 \mathrm{~m}$

4. Jembatan Tengah Danau

Sambil menikmati pemandangan danau yang indah para wisatawan bisa berswa foto yang menarik ditengah danau dengan menyebrangi jembatan yang menghubungkan bibir danau ke daratan yang ada di tengah danau.

$\begin{array}{ll}\text { Koordinat } & : 720158 ; 9266888 \\ \text { Elevasi } & : 982 \mathrm{~m}\end{array}$

Elevasi

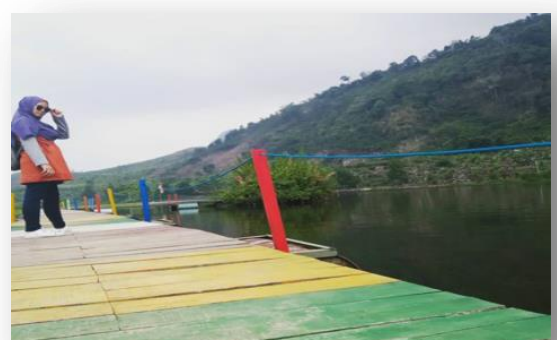

Gambar 3. Jembatan Tengah Danau 
5. Kolam Renang dan Kolam Ikan

Pihak pengelola Situ Rawa Gede juga menyediakan kolam renang bagi wisatawan yang ingin merasakan dinginnya air dari Bukit Kencana dan sambil menghilangkan kepenatan wisatawan bisa juga merasakan therapy kolam ikan dipinggir danau.
Koordinat
: $720171 ; 9266870$
Elevasi : $989 \mathrm{~m}$

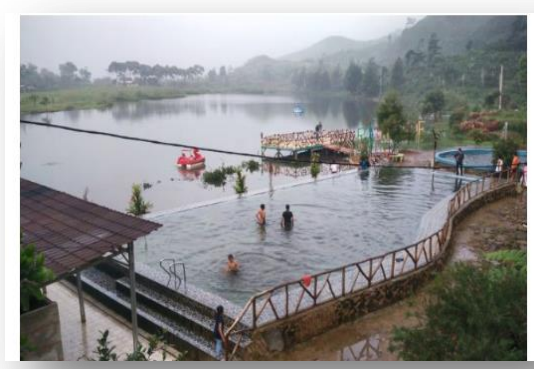

Gambar 4. Kolam Renang dan Kolam Ikan

\section{Camping Ground}

Bagi para wisatawan yang ingin merasakan bermalam di alam terbuka bisa mencoba camping ground yang telah disediakan oleh pengelola. Pihak pengelola menyediakan persewaan tenda sebagai pelindung bagi yang tidak membawa tenda.

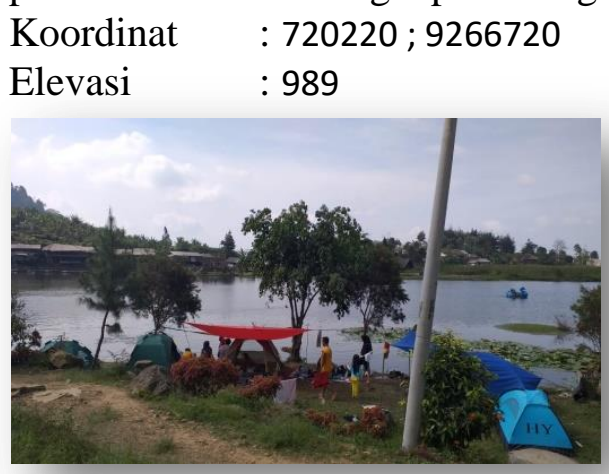

\section{Gambar 6. Camping Ground}

7. Sarana Ibadah

Meskipun sedang berwisata menikmati keindahan alam Situ Rawa Gede namun ibadah tidak boleh ditinggalkanterutama bagi yang beragama Islam, oleh karena itu pihak pengelola juga menyediakan Mushola yang berada di bibir danau sebagai tempat sarana ibadah bagi umat muslim.

Koordinat $: 720248 ; 9266813$

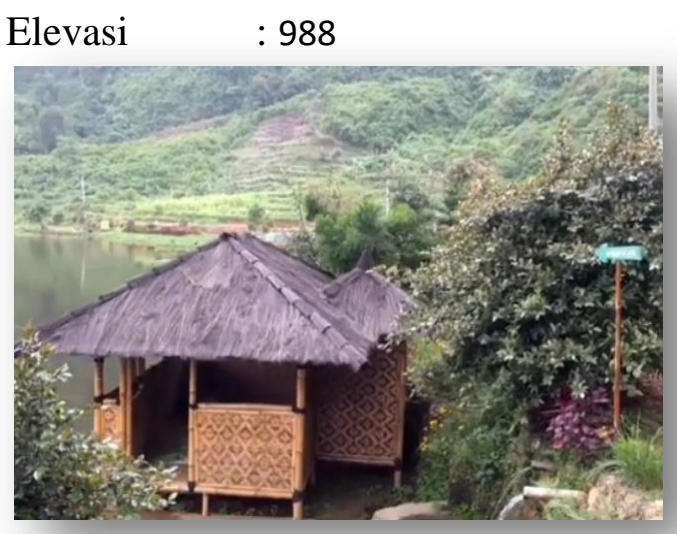

Gambar 6. Sarana Ibadah 


\section{Kebun Kopi}

Setelah puas mengelilingi Situ Rawa Gede wisatawan juga dimanjakan dengan perkebunan kopi yang lebat dan indah diatas ketinggian 1167 mdpl menuju Curug Cidulang. Masyarakat Sirnajaya mengembangkan perkebunan kopi berjenis Arabika dan Robusta dengan kualitas nomor 1.

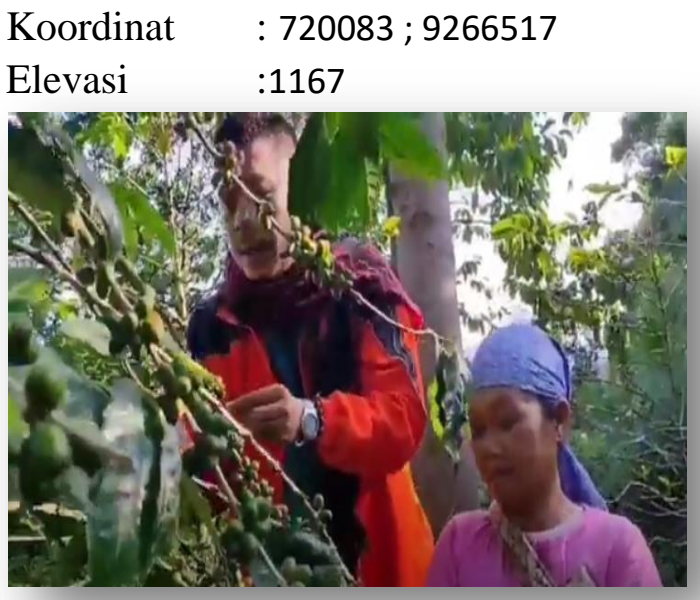

Gambar 8. Perkebunan Kopi

\section{Tempat Istirahat Menuju Curug Cidulang}

Untuk menghilangkan rasa lelah tracking menuju Curuk Cidulang para wisatwan disediakan tempat istirahat yang nyaman dan sejuk dengan semilirnya angin lembah dengan pemandangan yang sangat indah di ketinggian 1188 mdpl. Ditempat tersebut juga di sediakan tempat untuk berswa foto yang menarik.

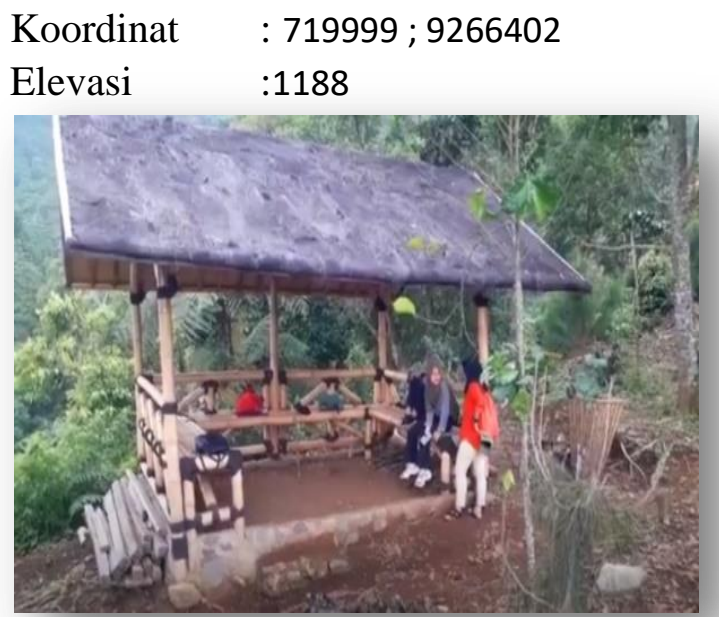

Gambar 9. Tempat Istirahat Menuju Curuk Cidulang

\section{Curug Cidulang}

Atas kebesaran yang Maha Kuasa Bukit Kencana di Desa Sirnajaya menyimpan banyak panorama yang enak dipandang oleh mata, salah satunya Curuk Cidulang yang berada di ketinggian 1188 mdpl. Curuk Cidulang salah satu yang ada di Kaki Bukit Kencana dengan suasana yang sejuk dan indah diiringi gemriciknya air pegunungan yang dingin menghilangkan rasa lelah setelah menyusuri jalur tracking yang menanjak.

Koordinat : 719989; 9266257

Elevasi 


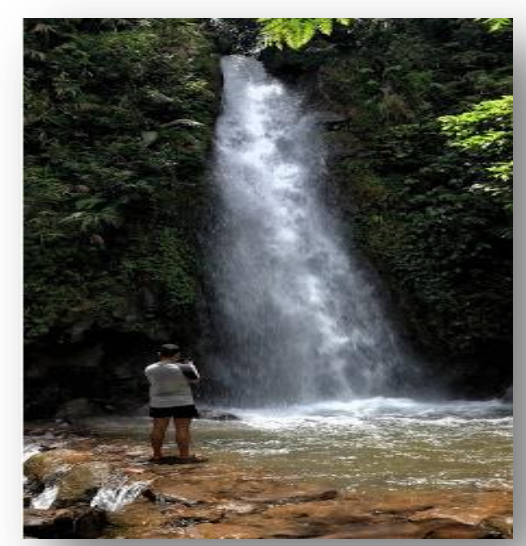

Gambar 10. Curuk Cidulang

\section{Pembuatan Peta Sebaran Fasilitas Wisata}

Data sebaran fasilitas Situ Rawa Gede diolah dengan menggunakan software Arcgis 10.3. Proses tersebut menghasilkan peta sebaran fasilitas Situ Rawa Gede Desa Sirnajaya Kecamatan Suka Makmur Kabupaten Bogor. Adapun peta sebaran fasilitas wisata tersebut bisa kita lihat pada gambar di bawah ini :
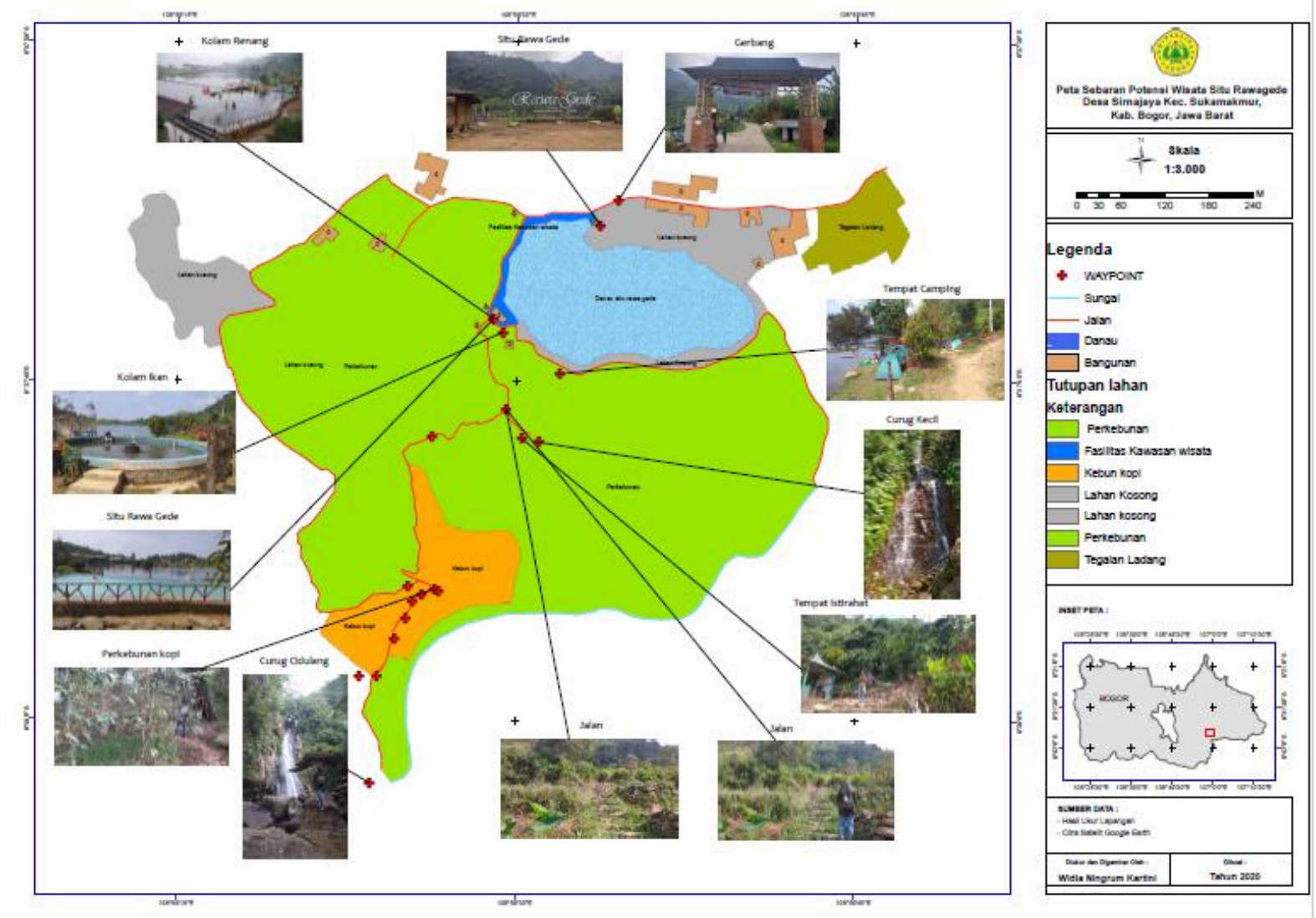

Gambar 10. Peta Sebaran Fasilitas Situ Rawa Gede

\section{Analisis}

Aksesbilitas menuju Situ Rawa Gede bisa melalui 3 jalur, yaitu :

1. Dari Jakarta

Dari Jakarta jarak tempuhnya kurang lebih2 jam melewatiTol Jagorawi menggunakan roda empat. Keluar tol, masuk Citeureup, lalu ambil arah kecamatan Sukamakmur. Setelah melewati kantor kecamatan, maka Anda tinggal menanjaki perbukitan sebelum sampai di telaganya. 
Bagi pengendara motor dari arah Jakarta, bisa melalui kawasan Cibubur dan Jonggol, Kabupaten Bogor. Setelah itu masuk jalur alternatif menuju Cipanas Puncak, dan tidak lama akan sampai di desa Sirnajaya, Kabupaten Bogor.

2. Dari Bogor

Sedangkan jika Anda dari Bogor anda bisa memilih lewat Sentul atau Jonggol, sebelum masuk Citeureup, lalu ambil arah Kecamatan Sukamakmur.

Sedangkan jika menggunakan sepeda motor, bisa melewati Kecamatan Cimahpar, melalui Sentul tepatnya Leuwihejo. Dari Leuwihejo, lalu masuk Citeureup ambil arah Kecamatan Sukamakmur.

3. Dari Cianjur

Satu lagi akses yang lebih dekat menuju wisata ini ialah dari Cipanas Puncak, Kabupaten Cianjur. Dari kawasan wisata Kota Bunga, Anda tinggal menelusuri jalan alternative menuju Jonggol dan Jakarta.Jalan tersebut akan melewati Kecamatan Sukamakmur, lalu Anda tinggal masuk ke desa Sirnajaya, sebelum masuk kawasan wisata Telaga Rawa Gede. Namun perlu berhati-hati setelah masuk Kecamatan Sukamakmur akan berkelokkelok melalui perbukitan,kadang jalannya curam kadang landai.

Obyek wisata dapat dikategorikan baik apabila memiliki daya tarik yang bagus, aksesbilitas yang mudah dan fasilitas yang memadai. Situ Rawa Gede meski memiliki 3 jalur aksesbilitas tetapi belum didukung infrastruktur jalan yang baik. Situ Rawa Gede sebelum dikelola oleh BUMDES (Badan Usaha Milik Desa) dikelola oleh swadaya masyarakat dengan jumlah pengunjung kurang lebih 6000 Orang per tahun, kemudian mulai tahun 2018 pengelolaan obyek wisata tersebut dikelola oleh BUMDES.

Semenjak dikelola oleh BUMDES jumlah pengunjung mengalami peningkatan $50 \%$ atau 12.000 orang/tahun dengan jumlah pendapatan sebesar 240 juta/tahun karena ada penambahan fasilitas dan perbaikan infrastruktur. Pada tahun 2019 akses jalan menuju Obyek wisata diperlebar dan juga penambahan sarana fasilitas lainnya, jumlah pengunjung mengalami peningkatan yang signifikan yaitu sebesar 40\% atau 30.000 orang per tahun.

Dengan peningkatan jumlah pengunjung diiringi pula jumlah pendapatan dari obyek wisata tersebut sebesar Rp. 600 juta/tahun, pendapatan tersebut belum ditambah dari pakir baik mobil maupun motor sebesar Rp. 65,357 juta/tahun dengan asumsi pengunjung yang membawa kendaraan mobil sebesar $30 \%$ dan motor $70 \%$ dan jumlah penumpang mobil berkapasitas 7 orang untuk motor 2 orang. Sehingga total pendapatan obyek wisata Situ Rawa Gede tahun 2019 sebesar 600 juta $+65,357$ juta $=$ Rp. 665,357 juta/tahun. Namun jumlah pengunjung mengalami penurunan yang sangat signifikan semenjak awal tahun 2020 sampai sekarang karena adanya pandemi covid 19 sebesar 70\%. Pendapatan tersebut didapat dari biaya masuk lokasi wisata Rp. 20.000/orang dan biaya parkir mobil Rp. 10.000, parkir motor Rp. 5.000.

\section{KESIMPULAN}

Berdasarkan hasil kajian pelaksanaan pemetaan partisipatif yang dilaksanakan oleh peneliti dan masyarakat dapat disimpulkan sebagai berikut :

1. Perlunya tata ruang Desa untuk pengembangan obyek wisata Situ Rawa Gede

2. Pelebaran aksesbilitas menuju Situ Rawa Gede sangat di perlukan karena akan semakin meningkatkan minat pengnjung untuk datang.

3. Penlitian ini bisa dijadikan acuan dalam penyusunan tata ruang obyek wisata situ rawa gede

\section{SARAN}

1. Pelatihan migitasi bencana sangat dibutuhkan karena Situ Rawa Gede di kelilingi oleh perbukitan 
2. Pemerintah Daerah memiliki peranan penting dalam pengembangan potensi wisata Situ Rawa Gede

3. Perlu adanya pelebaran aksesbilitas menuju tempat wisata Situ Rawa Gede

\section{DAFTAR PUSTAKA}

Choridotul B , Wahyu H, Sudarti, (2018), Strategi Pengembangan Potensi Pariwisata Di Pantai Duta Kabupaten Probolinggo, Jurnal Ilmu Ekonomi Vol 2 Jilid 1, Hal. 95 - 103

Damayanti, E. 2014. Strategi Capacity Building Pemerintah Desa dalam Pengembangan Potensi Ekowisata Berbasis Masyarakat Lokal (Studi di Kampoeng Ekowisata, Desa Bendosari, Kecamatan Pujon, Kabupaten Malang),Jurnal Administrasi Publik, Vol. 2, No. 3, hlm: 464-470.

ESP (2007) Buku Panduan Pemetaan Partisipatif Dengan Peta Kulihat Desaku. Environmental Services Program, DAI Project Number: 5300201. USAID/Indonesia. https://mimpi22.files.wordpress.com/2012/05/panduan_pemetaan_partisipatif.pdf

Hapsari H., \& Cahyono B.A., (2014), Pemetaan Partisipatif Potensi Desa (Studi Kasus: Desa Selopatak, Kecamatan Trawas, Kabupaten Mojokerto) GEOID Vol. 10, No. 01, DOI: 10.12962/j24423998.v10i1.705

Travel.Kompas.com, (2018), Apa Saja yang Bisa Dinikmati di Wisata Alam Telaga Rawa Gede Bogor?, di peroleh 03 Oktober 2020, dari https://travel.kompas.com/read/2018/01/21/205541327/apa-saja-yang-bisa-dinikmatidi-wisata-alam-telaga-rawa-gede-bogor?page $=$ all

Undang-undang Republik Indonesia, (2011), Informasi Geospasial, No. 04, BPK.go.id 